\title{
Human Alveolar Macrophage Growth Factor
}

\section{for Fibroblasts}

\author{
REGULATION AND PARTIAL CHARACTERIZATION
}

\author{
Peter B. Bitterman, Stephen I. Rennard, Gary W. Hunninghake, \\ and Ronald G. Crystal, Pulmonary Branch, National Heart, Lung, and \\ Blood Institute, National Institutes of Health, Bethesda, Maryland 20205
}

\begin{abstract}
A в S T RACT The number of fibroblasts composing the alveolar structures is controlled within narrow limits by a strictly modulated rate of fibroblast replication. One possible source of growth-modulating signals for alveolar fibroblasts is the alveolar macrophage, a member of the mononuclear phagocyte family of cells, which collectively are known to be important sources of growth factors for a variety of target cells. To evaluate the role of alveolar macrophages in the control of alveolar fibroblast replication, macrophages from normal individuals obtained by bronchoalveolar lavage were maintained in suspension culture with and without added stimuli, and supernates were evaluated for fibroblast growth-promoting effect. Supernates from unstimulated macrophages contained no growth factor activity. In marked contrast, supernates from macrophages stimulated with particulates and immune complexes contained a growth factor that caused a significant increase in fibroblast replication rate. Maximum growth factor activity was observed 3-4 h after macrophage stimulation, at a concentration of 1-2 $\times 10^{6}$ macrophages $/ \mathrm{ml}$. The alveolar macrophagederived growth factor eluted from DEAE-cellulose at $0.27 \mathrm{M} \mathrm{NaCl}$ at neutral $\mathrm{pH}$ had an apparent molecular weight of 18,000 , and appeared to be distinct from other characterized growth factors. The alveolar macrophage-derived growth factor stimulated lung fibroblast DNA synthesis within $12 \mathrm{~h}$, with cell division apparent within $48 \mathrm{~h}$. In serum-free culture, the alveolar macrophage-derived growth factor by itself did not promote fibroblast replication, but rather acted as a progression factor causing a synergistic increase in fibroblast replication rate in the presence of competence factors such as fibroblast growth factor or platelet-derived growth factor. These studies suggest that
\end{abstract}

Received for publication 21 December 1981 and in re vised form 11 June 1982. when stimulated, human alveolar macrophages may modulate, in part, the replication rate of alveolar fibroblasts by releasing a growth factor within the alveolar microenvironment.

\section{INTRODUCTION}

The fibroblast of the alveolar interstitium plays an important role in lung structure and function. Constituting $\sim 40 \%$ of the cells composing normal lung parenchyma (1), the fibroblast is the primary cell responsible for the production of connective tissue elements, the class of macromolecules that modulates lung mechanical properties and provides the structural milieu in which other parenchymal cells function. In addition, it is now recognized that alveolar fibroblasts may also be important in lung immunity, in regulating ventilation and perfusion relationships and thus gas exchange, and in providing the lung protection from proteolytic and oxidant injury (2-6).

It is apparent therefore, that the number of fibroblasts within the interstitium has a profound effect on the alveolar structures. Although it is generally recognized that these fibroblasts have a limited life span, the precise signals within the interstitial microenvironment that control alveolar fibroblast replication, and thus the fibroblast population size, have not been elucidated.

Current concepts of the regulation of cell division suggest that besides controls intrinsic to the cell, cellular replication is modulated by exogenous growth factors, a class of molecules that instructs cells to synthesize DNA and divide (7-10). In this context, regulation of alveolar fibroblast replication likely depends upon the presence of growth factors within the local milieu.

One possible source of growth factors for the alveolar fibroblast is the alveolar macrophage. This cell is 
a member of the mononuclear phagocyte series of cells, it constitutes $\sim 6 \%$ of the total cellular population of normal alveolar structures (11), and it resides in close anatomic relationship to the alveolar fibroblast. Mononuclear phagocytes are known to influence the replication rate of several types of cells. With regard to the bone marrow, mononuclear phagocytes secrete colonystimulating factor(s), glycoproteins capable of stimulating granulocyte-monocyte precursors to replicate (12). In addition, during the immune response, mononuclear phagocytes release interleukin-1, a 15,000-dalton growth factor that has a role in $T$ lymphocyte replication (13). Moreover, mononuclear phagocytes are known to be capable of releasing soluble factor(s) that cause fibroblasts to increase their rate of replication (14-18).

In light of these observations, the present study was designed to evaluate a role for the human alveolar macrophage as a source of a growth factor for human lung fibroblasts. The data demonstrate that a variety of stimuli induce human alveolar macrophages to release a growth factor for fibroblasts, and that this growth factor is distinct from other characterized growth factors.

\section{METHODS}

\section{Fibroblast cultures}

The normal human diploid fetal lung fibroblast strain, HFL-1 (American Type Culture Collection, Rockville, MD, CCL 153), previously frozen at passage 3 to 4 , was used in all experiments unless otherwise noted. Before use, the fibroblasts were thawed and cultured on $100-\mathrm{mm}$ tissue culture plates (Falcon Labware, Div. of Becton, Dickinson \& Co., Cockeysville, MD) in Dulbecco's modified Eagle medium (DMEM,' Gibco Diagnostics Laboratories, Grand Island, NY), supplemented with $10 \%$ calf serum (Colorado Serum Co., Denver, $\mathrm{CO}$ ) in an atmosphere of $10 \% \mathrm{CO}_{2}, 90 \%$ air at $37^{\circ} \mathrm{C}$. The fibroblasts were used for the growth factor assay between subcultivations 5 and 20 . Media were changed every other day and the cells subcultivated once a week.

\section{Growth factor assay}

To evaluate growth factor production by alveolar macrophages, supernates from macrophages cultured under various conditions were examined for their ability to stimulate noncycling lung fibroblasts to replicate.

Establishment of cultures of noncycling fibroblasts. The term "noncycling" lung fibroblasts will be used throughout this study to refer to a population of lung fibroblasts in which $<10 \%$ of the cells were synthesizing DNA during a 24-h period. (In comparison, $>90 \%$ of lung fibroblasts maintained in optimal culture conditions [DMEM plus $10 \%$ calf serum] synthesize DNA during a 24-h period.) The noncycling state was obtained by culturing fibroblasts in DMEM plus $0.4 \%$ calf serum for $\mathbf{4 d}$. The exact amount of serum needed to

\footnotetext{
'Abbreviation used in this paper: DMEM, Dulbecco's modified Eagle medium.
}

achieve the noncycling state was determined for the serum batch used by constructing a serum dose-fibroblast growth curve and choosing the highest concentration of serum that maintained fibroblasts in a noncycling, yet viable condition. The extent of DNA synthesis induced by the calf serum was evaluated by adding $0.5 \mu \mathrm{Ci} / \mathrm{ml}\left[{ }^{3} \mathrm{H}\right]$ thymidine (New England Nuclear, Boston, MA; $6.7 \mathrm{Ci} / \mathrm{mmol}$ ) to the fibroblast cultures, incubating for $24 \mathrm{~h}$ at $37^{\circ} \mathrm{C}$ and determining the proportion of fibroblast nuclei labeled with $\left[{ }^{3} \mathrm{H}\right]$ thymidine using previously described autoradiographic methods (19). Whereas lung fibroblasts maintained in DMEM plus $10 \%$ calf serum have a population doubling time of $1 \mathrm{~d}$, noncycling lung fibroblasts have a doubling time of at least $8 \mathrm{~d}$, consistent with the DNA synthesis data. Viability of noncycling lung fibroblasts was verified by demonstrating that $90 \%$ of the cells were able to synthesize DNA after exposure to DMEM plus $10 \%$ calf serum. In addition, $>95 \%$ of noncycling lung fibroblasts were able to exclude trypan blue.

Assessment of fibroblast growth. Noncycling fibroblasts for the growth factor assay were obtained by incubating confluent dishes of cells with trypsin $(0.25 \%$, Gibco). The detached fibroblasts were washed two times with 25 vol of DMEM plus $10 \%$ calf serum (to inactivate the trypsin) and then suspended in noncycling medium (DMEM plus $0.4 \%$ calf serum). Fibroblasts were then cultured in $2 \mathrm{ml}$ of noncycling medium on $35-\mathrm{mm}$ tissue culture dishes (Falcon) at the density specified (usually $10^{5}$ cells/dish). After incubation of fibroblasts for $4 \mathrm{~d}$, the medium was aspirated and $2 \mathrm{ml}$ of macrophage supernate (see below) were placed on each dish of fibroblasts. Noncycling medium served as a negative control and DMEM plus $10 \%$ calf serum served as a positive control. After the specified interval of fibroblast culture with the macrophage supernate, the cells were detached from culture dishes by incubation with trypsin and then counted in an electronic particle counter (Coulter Electronics Inc., Hialeah, FL, model ZBI).

\section{Alveolar macrophage cultures}

Alveolar macrophages were obtained from bronchoalveolar lavage cells recovered from normal individuals as previously described (20). Lavage cells were washed five times with $50 \mathrm{vol}$ of Hanks' balanced salt solution (Microbiological Associates, Walkersville, MD) after residual erythrocytes had been lysed in $150 \mathrm{mM} \mathrm{NH} 4 \mathrm{CL}, 10 \mathrm{mM} \mathrm{KHCO}_{3}$. In all cases Wright-Giemsa stained cytocentrifuge preparations confirmed that $>99 \%$ of cells were mononuclear with $>93 \%$ alveolar macrophages and the remainder lymphocytes. To evaluate macrophages for production of a growth factor for lung fibroblasts, macrophages $\left(10^{6} / \mathrm{ml}\right)$ were maintained in suspension culture $\left(37^{\circ} \mathrm{C} ; 4 \mathrm{~h}\right)$ with a variety of stimuli in the same noncycling medium used for the fibroblast cultures in 50-ml polypropylene conical tubes (Falcon 2070). (To prevent nonspecific stimulation of the macrophages, it was important to use tubes to which the macrophages do not attach.) After this incubation, macrophage supernates were removed and filtered through $0.22-\mu \mathrm{m}$ filters (Millipore Corp., Bedford, MA) and tested for fibroblast growth-promoting activity as described above. Macrophage supernates were assayed undiluted unless otherwise noted.

\section{Source of the growth factor for fibroblasts}

To be certain that alveolar macrophages were the sole source of the growth factor for fibroblasts, two approaches were used. 
First, lymphocytes were separated from macrophages by surface adherence of macrophages onto plastic tissue culture dishes as previously described (21). Adherent cells were $>99 \%$ macrophages and nonadherent cells were $>80 \%$ lymphocytes as determined by Wright-Giemsa-stained preparations. Adherent and nonadherent cells were cultured separately in plastic tissue culture dishes at a concentration of $10^{6}$ cells $/ \mathrm{ml}$ in noncycling medium with opsonized Sepharose for $4 \mathrm{~h}$ at $37^{\circ} \mathrm{C}$. Supernates of the adherent and nonadherent cells were then tested for fibroblast growth-promoting activity.

Second, unfractionated bronchoalveolar lavage cells were stimulated with opsonized Sepharose for $4 \mathrm{~h}$ and then separated into adherent and nonadherent populations. The purified cells were then washed three times with DMEM, cultured for $4 \mathrm{~h}$ as described above and the supernates tested for fibroblast growth-promoting activity

\section{Stimulation of alveolar macrophages to release the growth factor}

Six different conditions were used to stimulate alveolar macrophages to release the growth factor: (a) surface attachment; (b) zymosan (Sigma Chemical Co., St. Louis, MO) which was opsonized by incubating $1 \mathrm{ml}$ of boiled, washed particles in $10 \mathrm{ml}$ of fresh human serum $\left(37^{\circ} \mathrm{C}, 0.5 \mathrm{~h}\right)$, followed by eight washes in $\mathbf{5 0}$ vol DMEM before use; (c) Sepharose 4B (Pharmacia Fine Chemicals, Piscataway, NJ), which was opsonized in the same manner as zymosan; $(d)$ Staphylococcus albus (NIH Microbiological Service), which was heat killed and washed five times with $50 \mathrm{vol}$ of DMEM before use; (e) IgG immune complexes, and $(f)$ IgM-C3b immune complexes both prepared using ox erythrocytes and rabbit antibodies as previously described (22). To stimulate macrophages to produce growth factor, all agents were used at optimal concentrations determined by construction of dose-response curves: Sepharose or immune complexes were added at a final concentration of $1 \%(\mathrm{vol} / \mathrm{vol})$ to the macrophage incubation mixture; zymosan and $S$. albus were used at $5 \times 10^{7}$ particles $/ \mathrm{ml}$.

To determine the relative ability of various agents to stimulate alveolar macrophages to produce the growth factor, $10^{6}$ macrophages $/ \mathrm{ml}$ were incubated in suspension culture in noncycling medium at $37^{\circ} \mathrm{C}$ with Sepharose, zymosan $S$. albus, IgG immune complexes, or IgM C3b immune complexes, as described above; or allowed to attach to a tissue culture dish. After $4 \mathrm{~h}$ of macrophage incubation, supernates were assayed for growth factor activity. As a control, each stimulus was incubated in parallel under identical conditions without macrophages present and the resultant supernates were found to have no effect on fibroblast growth.

To clarify the role of the small amount of serum $(0.4 \%)$ present in the noncycling medium used for the macrophage incubations with the various stimulating agents, the experiment described above was also carried out in DMEM without serum. After the 4-h macrophage incubation with the stimulating agent, resultant supernates were supplemented with serum to a final concentration of $0.4 \%$ before assay for growth factor activity.

\section{Determination of kinetics of alveolar macrophage-derived growth factor release}

To determine the kinetics of growth factor release, alveolar macrophages $\left(10^{6} / \mathrm{ml}\right)$ were incubated in suspension cul- ture in noncycling medium at $37^{\circ} \mathrm{C}$ for various time intervals in the presence of either IgG immune complexes, $S$. albus, or opsonized Sepharose; or allowed to attach to a tissue culture dish. For all time points, supernates were harvested by aspiration and tested for growth factor activity. To determine whether the macrophages contained preformed active growth factor, unstimulated macrophages were first sonicated and the sonicates evaluated for growth factor activity.

\section{Dependence of growth factor release on the concentration of macrophages}

To determine the concentration dependence of growth factor release by alveolar macrophages, macrophages were incubated in suspension culture in noncycling medium at concentrations of $10^{4}$ cells $/ \mathrm{ml}$ through $10^{7}$ cells $/ \mathrm{ml}$ at $37^{\circ} \mathrm{C}$ for $4 \mathrm{~h}$ in the presence of opsonized zymosan. Supernates were filtered and assayed for growth factor activity.

\section{Partial purification of the alveolar macrophage-derived growth factor}

To produce sufficient amounts of growth factor for partial purification, a total of $10^{8}$ alveolar macrophages from eight normal individuals (cultured individually) were allowed to attach to $100-\mathrm{mm}$ tissue culture dishes $\left(10^{7}\right.$ cells $\left./ \mathrm{dish}\right)$ in 10 $\mathrm{ml}$ of DMEM without serum; DMEM without serum was used to avoid contamination of the preparation with large quantities of serum proteins and to avoid confusion with the numerous growth factors known to be present in serum. After $45 \mathrm{~min}$, nonadherent cells were removed. The adherent macrophages were cultured at $37^{\circ} \mathrm{C}$ in serum-free DMEM containing opsonized zymosan with the media replaced every $4 \mathrm{~h}$ for $16 \mathrm{~h}$ total. Supernates from each individual were stored frozen in liquid nitrogen vapor. When $\sim 1 \mathrm{mg}$ of protein had been accumulated (representing $\sim 300 \mathrm{ml}$ of macrophage supernates), the supernates were pooled and used for partial purification of the growth factor. Protein concentrations were determined using a colorimetric assay (Bio-Rad Laboratories, Richmond, CA) with bovine serum albumin as a standard. To determine whether the alveolar macrophage-derived growth factor could be released in a completely serum-free system, opsonized zymosan was omitted from the macrophage cultures and supernates containing $0.16 \mathrm{mg}$ protein from $5 \times 10^{7}$ adherent alveolar macrophages from the same eight normals cultured individually were processed in parallel. All chromatography was carried out at $4^{\circ} \mathrm{C}$.

Ion exchange chromatography. For the first purification step, supernates from stimulated alveolar macrophages were dialyzed (20 vol, three changes) against starting buffer (20 $\mathrm{mM} \mathrm{NaCl} ; 20 \mathrm{mM}$ Tris- $\mathrm{HCl}, \mathrm{pH}$ 7.0) and then chromatographed on a DEAE-cellulose column (DE-52, Whatman, Kent, England; $10 \mathrm{~g}$ dry resin/mg of protein in the macrophage supernates), which had been preequilibrated with starting buffer. The column was washed with 10 bed vol of starting buffer and then eluted with 4 bed vol of a salt gradient $(20-300 \mathrm{mM} \mathrm{NaCl}$ in the same buffer followed by a $1.0-\mathrm{M} \mathrm{NaCl}$ step) and collected in 5-ml fractions. Each fraction was dialyzed ( 500 vol, 2 changes) against DMEM. After dialysis, calf serum was added to each fraction to a final concentration of $0.4 \%$ before assay for growth factor activity on noncycling fibroblasts. To quantitate the amount of growth factor recovered, serial dilutions of the fractions with activity were carried out. 
Gel filtration. To further purify the alveolar macrophage-derived growth factor the two adjacent fractions from the DEAE-cellulose column with maximum growth factor activity were chromatographed on a $700-\mathrm{ml}$ bed vol column (Pharmacia Fine Chemicals, $5 \times 60 \mathrm{~cm}$, flow rate $8 \mathrm{ml} / \mathrm{h}$ ) of Sephadex G-75 (Pharmacia Fine Chemicals), equilibrated in phosphate-buffered saline without calcium or magnesium, pH 7.4 (Gibco Laboratories). The column was calibrated with blue dextran, ovalbumin, chymotrypsinogen A, ribonuclease A, (all from Pharmacia Fine Chemicals); insulin and bacitracin, (Calbiochem-Behring Corp., American Hoechst Corp., La Jolla, CA). 75 fractions ( $10 \mathrm{ml}$ each) were collected and assayed for growth factor activity as described above. Serial dilutions of the active fractions were performed to quantitate growth factor recovery.

\section{Relationship of the alveolar macrophage- derived growth factor to other characterized growth factors}

To determine the relationship of partially purified alveolar macrophage-derived growth factor to partially purified platelet-derived growth factor (prepared as described by Vogel et al. [23]) and fibroblast growth factor (Collaborative Research Inc., Waltham, MA), each of these factors was chromatographed on DEAE-cellulose in separate column runs. Each factor was detected by its growth-promoting activity for fibroblasts in a manner identical to that described above. The relationship of the macrophage factor to insulin and epidermal growth factor (Collaborative Research) was evaluated by molecular weight determined by gel filtration chromatography with Sephadex G-75. Insulin was detected by its optical density at $280 \mathrm{~nm}$ and epidermal growth factor was detected by its growth promoting activity for fibroblasts. Comparison with human growth hormone was carried out by radioimmunoassay using the method of Odell et al. (24). The relationship to somatomedin $A$, somatomedin $C$, multiplication stimulating activity, and insulinlike growth factors I and II was assessed by radioreceptor assays using the methods of Moses et al. (25) and Rechler et al. (26). The relationship to multiplication stimulating activity and somatomedin $\mathrm{C}$ was also assessed by radioimmunoassay by the method of Moses et al. (27) and Furlanetto et al. (28), respectively. Comparison with interleukin-1 was carried out by testing alveolar macrophage-derived growth factor in a standard interleukin-1 mouse thymocyte assay (29) and by testing human blood monocyte interleukin-1 in the fibroblast growth assay. An interleukin-1 standard was prepared as described by Mizel et al. (30); supernates of lipopolysaccharide-stimulated adherent human blood monocytes were concentrated and chromatographed on Sephadex G-75 with the active fractions (apparent mol wt 15,000) identified by their ability to cause mouse thymocytes to synthesize DNA. The interleukin-1 standard had no interleukin-2 activity, as determined by the method of Gillis et al. (31)

\section{Effect of partially purified growth factor on fibroblast DNA synthesis}

To determine the effect of partially purified alveolar macrophage-derived growth factor on fibroblast DNA synthesis, an active fraction from the DEAE cellulose column was diluted 1:100 with noncycling medium containing $\left[{ }^{3} \mathrm{H}\right]-$ thymidine $(2 \mu \mathrm{Ci} / \mathrm{ml}, 6.7 \mathrm{Ci} / \mathrm{mmol}$, New England Nuclear, Boston, MA) and placed on noncycling fibroblasts $\left(3 \times 10^{5}\right)$ 35-mm dish). At several time points after growth factor addition, fibroblasts on replicate plates were evaluated for the incorporation of $\left[{ }^{3} \mathrm{H}\right]$ thymidine into acid precipitable counts, as previously described (32). To correct for $\left[{ }^{3} \mathrm{H}\right]$ thymidine incorporation unrelated to growth factor addition, four control plates were assayed in parallel at each time point and this value (which ranged from $200 \pm 150$ at $2 \mathrm{~h}$ to $1,000 \pm 125$ at $24 \mathrm{~h}$ ) was subtracted from the value determined with growth factor present.

\section{Effect of partially purified alveolar macrophage-derived growth factor on fibroblast replication in serum-free medium (complementation test)}

One useful system for classifying growth factors has been proposed by Stiles et al. (33), who have described a complementation test that allows classification of a growth factor as either a "progression" factor (e.g., multiplication-stimulating activity) or a "competence" factor (e.g., fibroblast growth factor, platelet-derived growth factor), according to its position of action within the cell cycle. In this context, these investigators have suggested that fibroblasts require the presence of both a competence factor and a progression factor to replicate. To evaluate the alveolar macrophagederived growth factor in this regard, a complementation test was performed in which the alveolar macrophage-derived growth factor was paired with either a characterized competence factor or a characterized progression factor and the effect on fibroblast replication assessed. Serum-free conditions were used for this assay so that the effect of the growth factors of interest could be directly evaluated without the complex interactions of these growth factors with undetermined serum constituents.

To establish the complementation test, fibroblasts were removed from a tissue culture dish by brief incubation in trypsin $\left(1 \mathrm{~min}, 22^{\circ} \mathrm{C}\right)$ and cultured at $10^{5}$ cells $/ 35-\mathrm{mm}$ dish in noncycling media for $2 \mathrm{~d}$. On days 3,4 , and 5 , fibroblast cultures were washed three times with complementation test medium (DMEM containing $1 \mathrm{mg} / \mathrm{ml}$ bovine serum albumin [radioimmunoassay grade, Sigma Chemical]) and fresh complementation test medium was added. After this interval, no cell division was observed without subsequent addition of growth factors.

On day 5 , the macrophage factor was added to the fibroblast cultures with either a progression factor (multiplication-stimulating activity, $2 \mathrm{ng} / \mathrm{ml}$ ) or with a competence factor (either fibroblast growth factor, $2 \mathrm{ng} / \mathrm{ml}$, or plateletderived growth factor, $0.1 \mathrm{U} / \mathrm{ml}$ ). As negative controls, each factor was used alone to confirm that fibroblast replication did not occur. As a positive control, multiplication-stimulating activity was added to the serum-free fibroblast culture with either platelet-derived growth factor or fibroblast growth factor. In all cases, after growth factor addition, fibroblasts were incubated at $37^{\circ} \mathrm{C}$ for $3 \mathrm{~d}$, and then counted.

To confirm that alveolar macrophage-derived growth factor acted as a progression factor, fibroblasts were cultured in complementation test medium at $3.0 \times 10^{5}$ Cells $/ 35-\mathrm{mm}$ dish in a manner identical to that described above. Dilutions of partially purified alveolar macrophage-derived growth factor, $0.1 \mathrm{U} / \mathrm{ml}$ of platelet-derived growth factor (which by itself had no effect on $\left[{ }^{3} \mathrm{H}\right]$ thymidine incorporation), and $2 \mu \mathrm{Ci} / \mathrm{ml}$ of $\left[{ }^{3} \mathrm{H}\right]$ thymidine were added to the fibroblasts in complementation test medium. $24 \mathrm{~h}$ later, the plates were 
evaluated for $\left[{ }^{3} \mathrm{H}\right]$ thymidine incorporation. $\left[{ }^{3} \mathrm{H}\right]$ thymidine incorporation in medium without added growth factors $(1,200 \pm 130)$ was subtracted from each data point.

\section{Effect of partially purified alveolar macrophage-derived growth factor on the replication of five human lung fibroblast strains}

To establish that the growth promoting effects of the alveolar macrophage-derived growth factor were not restricted to HFL-1 cells, two human diploid fetal lung fibroblast strains (HFL-1 and P-7) and three human diploid adult lung fibroblast strains obtained by primary culture of specimens of normal lung (86, American Type Culture Collection [ATCC]CCL 190), 47 [ATCC CCL 135], and 22) were used. These primary cultures of fibroblasts were initiated in the same manner as HFL-1, using the method of Bradley et al. (34). These fibroblast strains were cultured as described above for the complementation test using platelet derived growth factor $(0.1 \mathrm{U} / \mathrm{ml})$ as the competence factor. For each strain, a fibroblast growth curve was constructed using different doses of partially purified macrophage-derived growth factor as the progression factor.

\section{Statistical evaluation}

Since the growth factor assay was performed in duplicate, with duplicate culture dishes varying by $<5 \%$, these values were expressed as the mean without error bars. Macrophage stimulation experiments were performed with duplicate stimulations, with each of the two resultant supernates placed on duplicate fibroblast cultures for the growth factor assay. The resulting number of fibroblasts was then expressed as the mean of the four values \pm SD. Thymidine incorporation experiments were performed in quadruplicate with data expressed as the mean \pm SD. All comparisons between mean values were performed using an analysis of variance.

\section{Quantitation of alveolar macrophage- derived growth factor}

The amount of growth factor present in a sample was experimentally determined by defining the fibroblast growth response to a set of dilutions of that sample, using principles described by Burn et al. (35). To quantitate the amount of growth factor in a sample, the maximum increase in fibroblast number for the sample was found and the reciprocal of the dilution of the sample resulting in one-half of this maximum increase in fibroblast number was taken to represent the relative quantity of growth factor present. The quantity of growth factor is presented with error bars derived from the $95 \%$ confidence limits of the one-half maximum growth response (a value derived from the $95 \%$ confidence limits of the straight line connecting the experimental values flanking the calculated midpoint). Statistical comparisons of the dose-response curves for different samples were performed using the Wilcoxon rank-order test, which weights each value on the dose-response curve equally.

\section{RESULTS}

Fibroblast growth in response to alveolar macrophage-derived growth factor. Alveolar macrophages from normal individuals incubated in suspension culture with opsonized Sepharose released an activity that increased the growth rate of noncycling human lung fibroblasts (Fig. 1). When trypsinized fibroblasts were placed in noncycling medium, their rate of replication progressively decreased for 2-3 d until a stable low rate of replication was established. Exposing the fibroblasts to supernates from stimulated macrophages on the 4th day of fibroblast culture in noncycling media resulted in a substantial increase in fibroblast replication rate which was apparent within $2 \mathrm{~d}$. In the example shown, whereas cell numbers increased $62 \%$ with supernates of stimulated macrophages, fibroblasts exposed to supernates from unstimulated macrophages increased in number by only $16 \%$ in the same time

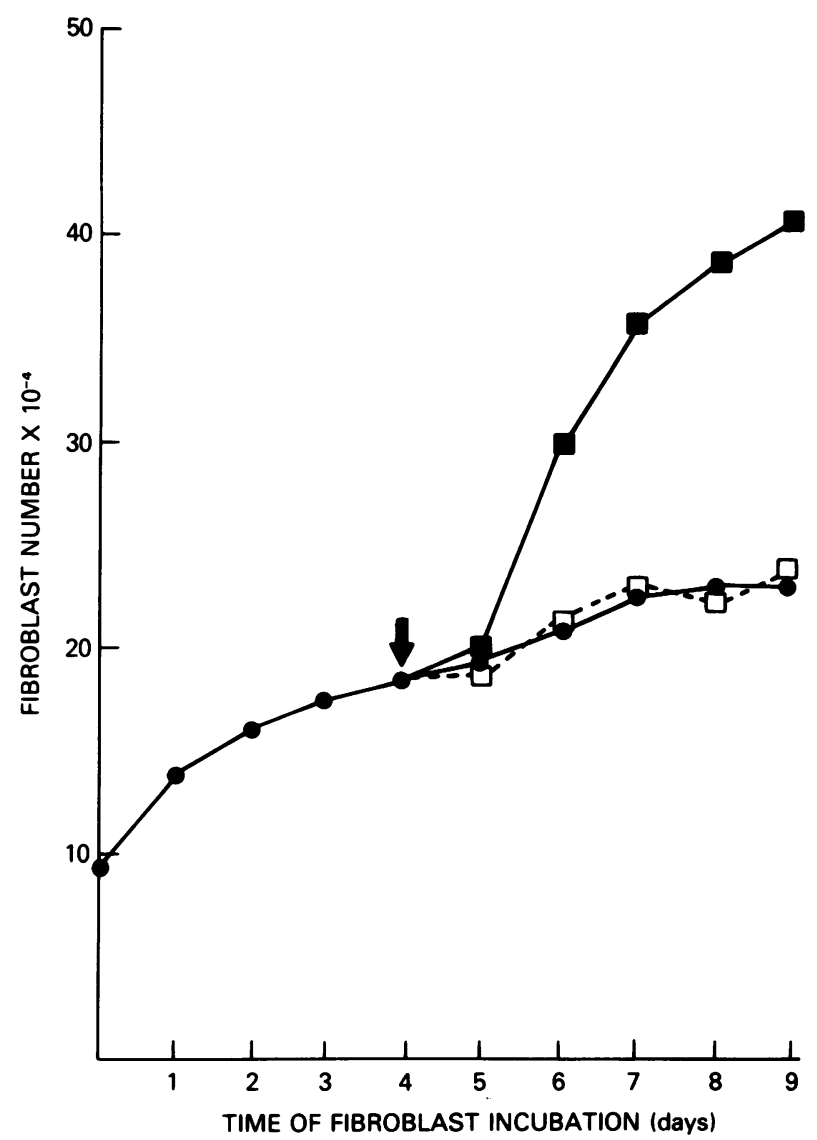

FIGURE 1 Influence of human alveolar macrophages on fibroblast growth. Alveolar macrophages $\left(10^{6} / \mathrm{ml}\right)$ from a normal individual were cultured in suspension $\left(37^{\circ} \mathrm{C}, 4 \mathrm{~h}\right)$ with either Sepharose or no stimulus. Supernates were placed on noncycling fibroblasts at the time indicated by the arrow. On each day, fibroblasts from duplicate plates were counted. Shown are fibroblast numbers in response to supernates of Sepharose-stimulated macrophages (ש), unstimulated macrophages $(\square)$, or medium alone $(\bullet)$. 
period, a value similar to that observed when fibroblasts were cultured in noncycling medium alone. The difference in fibroblast growth rate was still apparent $5 \mathrm{~d}$ after macrophage supernate addition; fibroblasts cultured with supernates from stimulated macrophages had increased in number by $130 \%$, fibroblasts cultured with supernates from unstimulated macrophages increased in number by only $20 \%$, and fibroblasts in noncycling medium increased in number by $17 \%$.

Although all of the cell preparations used for these studies were $>93 \%$ macrophages, formal demonstration that the source of the growth factor was macrophages and not lymphocytes was provided by studies in which bronchoalveolar lavage cells were separated into adherent (macrophages) and nonadherent (lymphocytes) fractions. Supernates of macrophages incubated for $4 \mathrm{~h}$ in the presence of opsonized Sepharose resulted in a $60 \%$ increase in fibroblast number within $2 \mathrm{~d}$ and a $136 \%$ increase in fibroblast number by $5 \mathrm{~d}$; values similar to those obtained from unfractionated cells. In marked contrast, supernates from lymphocytes had no influence on fibroblast replication. Moreover when unfractionated bronchoalveolar lavage cells were incubated for $4 \mathrm{~h}$ in suspension culture in the presence of opsonized Sepharose, washed in noncycling medium, and then separated into macrophage and lymphocyte fractions, all of the growth-promoting activity during a subsequent $4-\mathrm{h}$ culture of the two cellular fractions was found in the supernates of the macrophages. Thus, under these conditions, macrophages were the sole source of growth-promoting activity for fibroblasts (data not shown).

Quantitation of alveolar macrophage-derived growth factor. An estimate of the quantity of alveolar macrophage-derived growth factor in a sample was provided by the reciprocal of the dilution corresponding to onehalf of the maximum growth response for that sample (Fig. 2). In the example shown, Supernates from macrophages incubated with opsonized Sepharose resulted

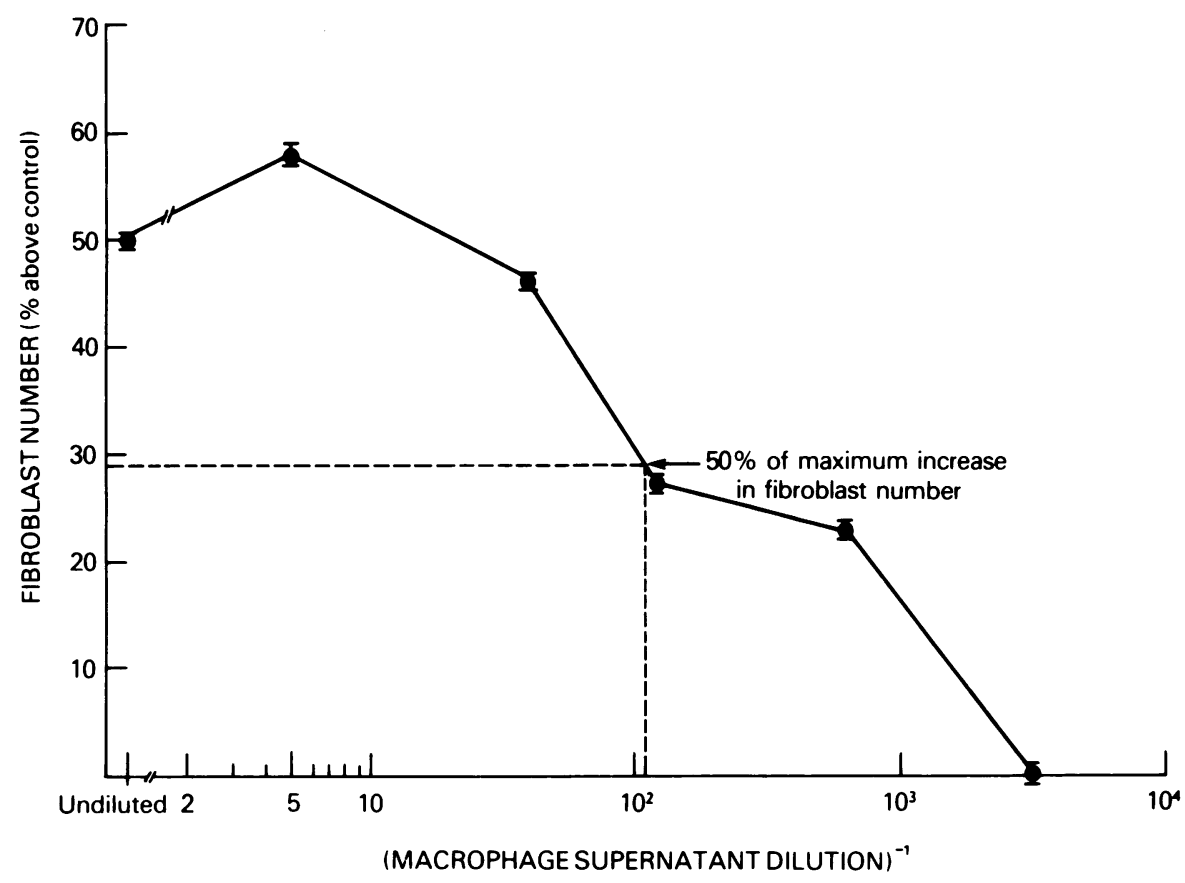

FIGURE 2 Quantitation of alveolar macrophage-derived growth factor. To quantitate the amount of growth factor present, each condition studied was evaluated by determining fibroblast growth in response to increasing dilutions of alveolar macrophage-derived growth factor. In the example given, alveolar macrophages $\left(10^{6} / \mathrm{ml}\right)$ were cultured in suspension with opsonized Sepharose and the resultant supernates were placed on noncycling fibroblasts for $48 \mathrm{~h}$. Fibroblast growth was expressed as the percentage increase in cell number above control. The horizontal dashed line intersects the curve at a value representing the half-maximum increase in fibroblast growth (29\%). The vertical dashed line intersects the abscissa at that dilution of supernate (104) (expressed as a reciprocal) corresponding to the half-maximum increase in fibroblast growth. The value 104 was taken as an estimate of the relative amount of growth factor present in the macrophage supernate. 
in a maximum increase of fibroblast number above control of 58\%. The half-maximum increase in fibroblast number above control was therefore $29 \%$, corresponding to a reciprocal dilution of 104 . The reciprocal dilution values obtained by such analyses provided an approximate estimate of the relative quantity of growth factor in the macrophage supernates.

Kinetics of growth factor release by alveolar macrophages. Evaluation of sonicates of alveolar macrophages revealed no preformed active growth factor. Supernatants of unstimulated macrophages maintained in suspension culture for $4 \mathrm{~h}$ at no time produced an increase in fibroblast replication rate (Fig. 3A). In contrast, when macrophages were incubated in suspension culture with IgG immune complexes, S. albus, or opsonized Sepharose; or allowed to attach to a tissue culture dish, growth-promoting activity was observed in the supernatants within $75 \mathrm{~min}$. For IgG immune complexes, $S$. albus, and opsonized Sepharose, the majority of growthpromoting activity was present in the supernate by 75 min, with maximal activity observed between 3 and 4 h. In contrast, attachment of the alveolar macrophages to a tissue culture plate resulted in a slower release of growth-promoting activity. However, in common with the other agents, maximal activity was observed between 3 and $4 \mathrm{~h}$. Continued culture of the stimulated macrophages in each group for up to $24 \mathrm{~h}$ resulted in little further increase in growth promoting activity (data not shown).

Dependence of growth factor release on the concentration of macrophages. An assessment of the dependence of growth factor release on the concentration of macrophages (stimulated with opsonized zymosan) revealed no detectable growth-promoting activity with $<5 \times 10^{4}$ macrophages $/ \mathrm{ml}$ (Fig. 3B). Progressively more growth-promoting activity was detectable with increasing cell concentration up to $1-2 \times 10^{6}$ macrophages $/ \mathrm{ml}$; at this concentration, one-half of the maximum increase in fibroblast number occurred at a supernatant dilution of $\sim 1: 125$, i.e., a relative activity of 125 . Higher cell
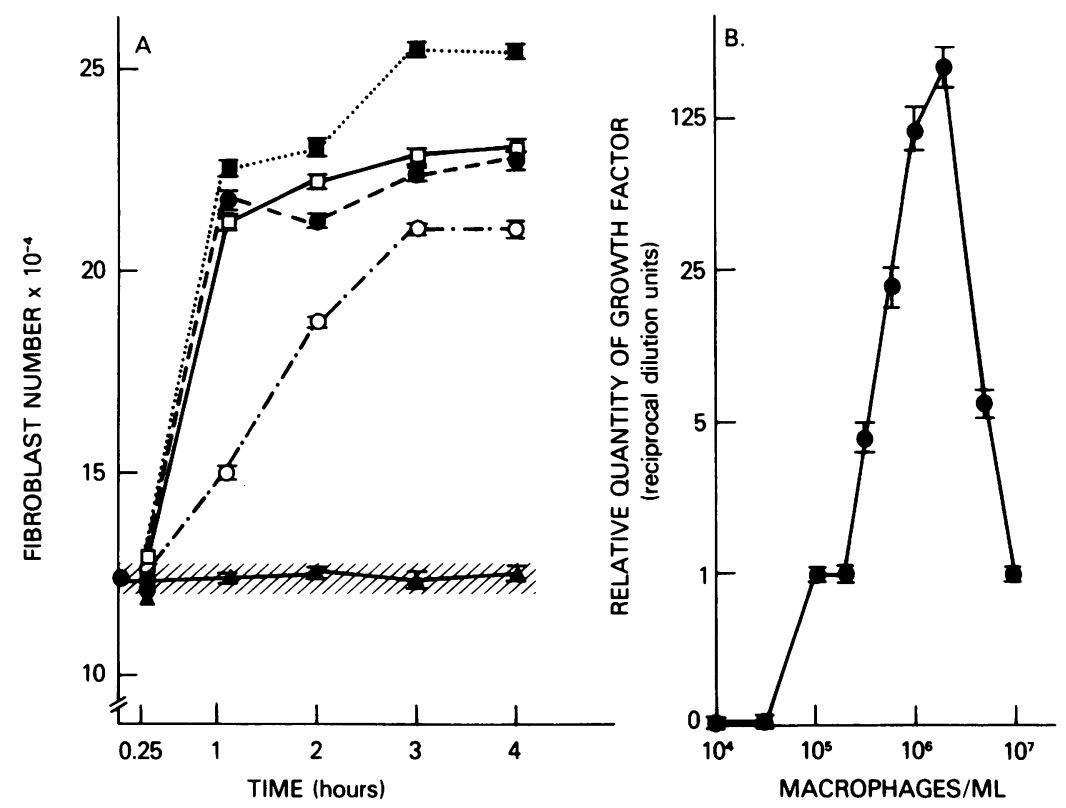

Figure 3 Parameters of growth factor release by alveolar macrophages. (A) Kinetics of growth factor release by stimulated macrophages. At zero time, normal alveolar macrophages

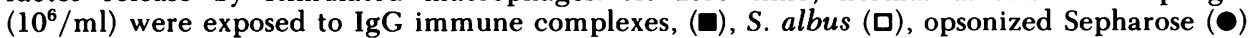
or no stimulus $(\Delta)$ in suspension culture; or allowed to attach to a tissue culture dish $(O)$. The cells were then cultured at $37^{\circ} \mathrm{C}$ for the times indicated. For each time point, supernates were incubated $48 \mathrm{~h}$ with noncycling fibroblasts. Shown is fibroblast growth in the presence of macrophage supernates as a function of the time of macrophage incubation with the stimulating agent. Shaded area represents fibroblast number (mean $\pm 2 \mathrm{SD}$ ) after $48 \mathrm{~h}$ incubation in noncycling medium alone. (B) Dependence of growth factor release on concentration of macrophages. Normal alveolar macrophages stimulated with zymosan were cultured $\left(37^{\circ} \mathrm{C}, 4 \mathrm{~h}\right)$ at the cell concentrations indicated. Supernates were then incubated for $48 \mathrm{~h}$ with noncycling fibroblasts. Indicated is the relative amount of growth factor present in each macrophage supernate (determined using the analysis outlined in the legend to Fig. 2) as a function of the macrophage concentration. 
concentrations resulted in a decrease in growth-promoting activity of the macrophage supernates; with $10^{7}$ cells/ $\mathrm{ml}$ only undiluted supernates caused an increase in fibroblast replication rate.

Ability of various agents to stimulate the release of alveolar macrophage-derived growth factor. Several agents were capable of stimulating alveolar macrophages to release the growth factor for fibroblasts, but the relative growth-promoting activity of the resultant supernates was different for different groups of agents (Fig. 4). Macrophages stimulated with IgG immune complexes through Fc receptors or with IgM-C3b immune complexes through $\mathrm{C} 3 \mathrm{~b}$ receptors released the largest amount of growth factor (relative activity 125); S. albus, opsonized zymosan, and opsonized Sepharose resulted in an

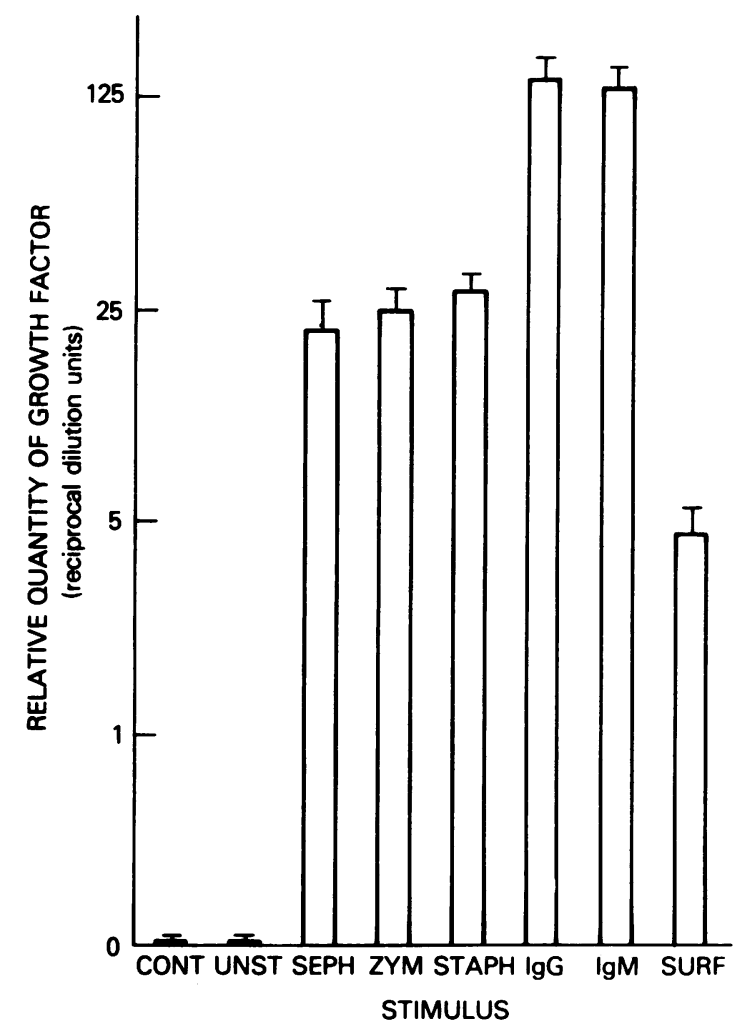

Figure 4 Relative ability of various agents to stimulate normal alveolar macrophages to release the growth factor for fibroblasts. Cultures were carried out under the following conditions: (a) media without macrophages (CONT, control), (b) macrophages in suspension alone (UNST, unstimulated); macrophages maintained in suspension with: $(c)$ opsonized Sepharose (SEPH), $(d)$ opsonized zymosan (ZYM), $(e)$ heatkilled $S$. albus (STAPH), (f) IgG-immune complexes (IgG), (g) IgM-complement-immune complexes (IgM), (h) macrophages allowed to attach to a plastic culture dish (SURF, surface). After a $4 \mathrm{~h}$ incubation at $37^{\circ} \mathrm{C}$, supernates were placed on noncycling fibroblasts for $48 \mathrm{~h}$ and the relative amount of growth factor present was determined using the analysis outlined in the legend to Fig. 2. intermediate amount of growth factor release each with a relative activity of $\sim 25$; and surface attachment resulted in the least amount of growth factor release with a relative activity of 5 . In contrast, unstimulated macrophages did not release any growth factor. Rank-order analysis revealed the difference among groups was significant $(P<0.01$, all comparisons). In addition, for each stimulating agent, alveolar macrophages released the same amount of growth factor when cultured in DMEM without serum, as when cultured in noncycling medium containing $0.4 \%$ serum, which suggests that serum was not required for growth factor release (data not shown).

Partial purification of the alveolar macrophage-derived growth factor. Partial purification of the growth factor was accomplished by anion exchange chromatography followed by gel filtration. Approximately 1 $\mathrm{mg}$ of protein from cultures of zymosan-stimulated macrophages was chromatographed on DEAE-cellulose. The growth-promoting activity for fibroblasts bound to the anion exchange resin at neutral $\mathrm{pH}$ with the major peak of activity eluting at $\sim 0.27 . \mathrm{M} \mathrm{NaCl}$ (Fig. 5A). This peak contained $\sim 1.2 \mu \mathrm{g}$ protein and a total relative growth promoting activity of $10^{5}$. Gel filtration of the major DEAE cellulose peak on Sephadex G-75 revealed one significant peak of fibroblast growth-promoting activity with an apparent molecular weight of 18,000; this peak contained $60 \mathrm{ng}$ protein with a total relative growth promoting activity of $10^{4}$. Thus, assuming a molecular weight of 18,000 , the alveolar macrophage-derived growth factor appears to be active in the nanomolar to picomolar range. To exclude the possibility that the small amount of serum adsorbed to the zymosan was required for growth factor production, chromatography of $0.16 \mathrm{mg}$ of secretory protein from macrophages stimulated in an entirely serum-free system by adherence to a tissue culture dish was carried out. This resulted in identical ion-exchange and gel-filtration peaks (data not shown).

During both ion-exchange and gel-filtration chromatography, undiluted column fractions were found with some fibroblast growth-promoting activity that was clearly distinct from the main peak of bioactivity. However, since these fractions contained $<0.01 \%$ of the total recoverable growth factor activity and did not have reproducible elution profiles, they were not analyzed further.

Effect of partially purified macrophage-derived growth factor on fibroblast DNA synthesis. The kinetics of DNA synthesis after incubation of noncycling fibroblasts with partially purified growth factor was characterized by a lag in DNA synthesis of $\sim 12 \mathrm{~h}$ (Fig. 6). DNA synthesis then continued for at least $24 \mathrm{~h}$, consistent with the increase in cell number observed at $48 \mathrm{~h}$.

Serum-free complementation test. A serum-free 

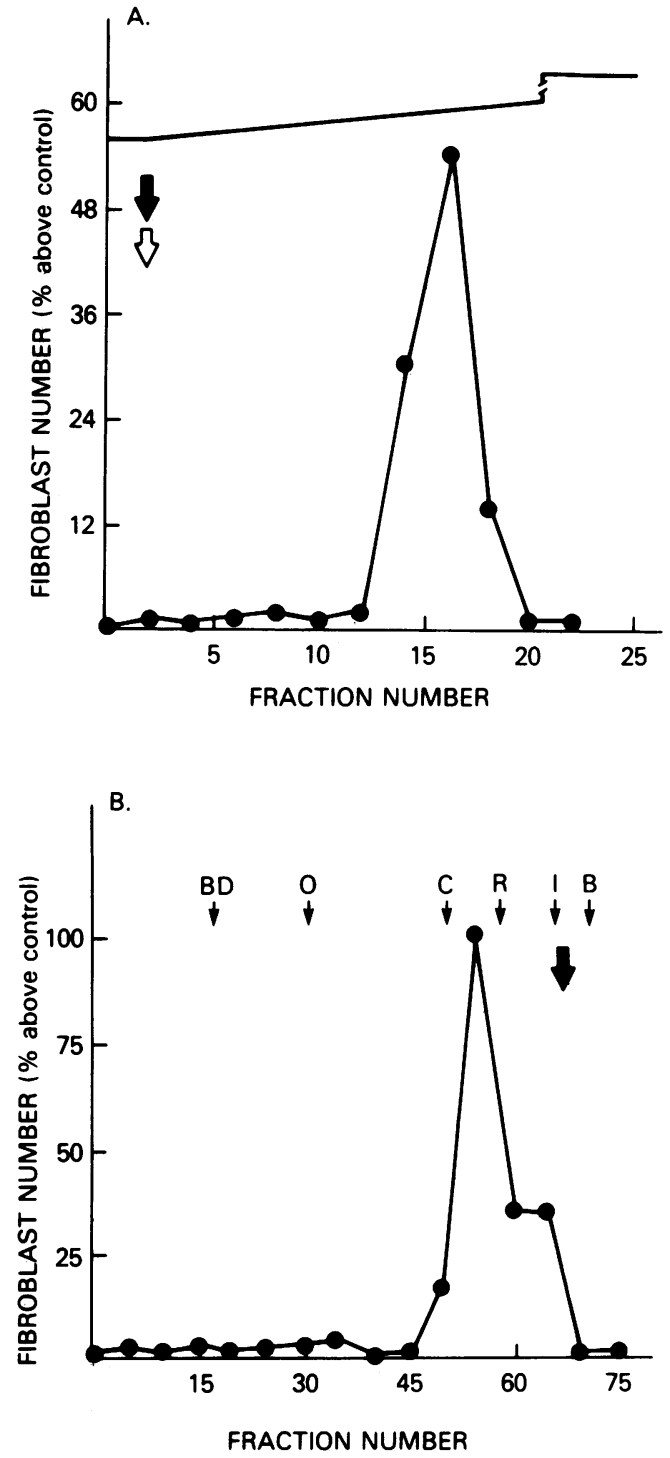

Figure 5 Partial purification of alveolar macrophage-derived growth factor. (A) DEAE-cellulose chromatography of stimulated macrophage supernates. Normal alveolar macrophages were stimulated with zymosan and the resulting supernates (total $300 \mathrm{ml}$ ) chromatographed on DEAE-cellulose and eluted with a salt gradient as indicated. Fractions $(5 \mathrm{ml})$ were collected, diluted 1:100, and assayed for growth factor activity. Arrows indicate position of elution of platelet derived growth factor ( ) and of fibroblast growth factor $(D)$, which were chromatographed separately. (B) Gel filtration of the DEAE-cellulose partially purified alveolar macrophage derived growth factor. A $10-\mathrm{ml}$ sample (fractions 16 and 17) from the DEAE-cellulose column was chromatographed on Sephadex G-75 and fractions evaluated for growth factor activity. Standards (arrows) included: blue dextran (BD, $2 \times 10^{6}$ daltons); ovalbumin (O, 45,000 daltons); chymotrypsinogen $\mathrm{A}(\mathrm{C}, 25,000$ daltons); ribonuclease A ( $R, 13,700$ daltons); insulin (I, 6,000 daltons); and bacitracin (B, 1,400 daltons). Arrow ( $)$ indicates the position of elution of epidermal growth factor which was chromatographed separately.

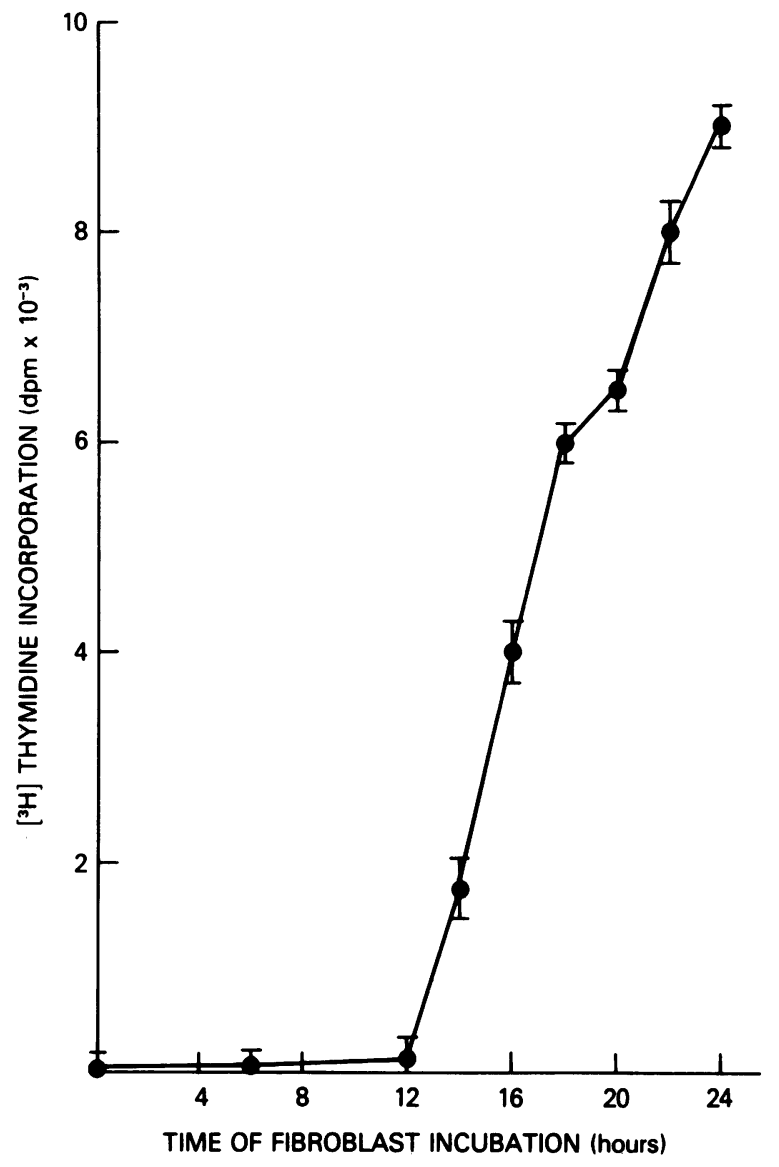

Figure 6 Alveolar macrophage-derived growth factor stimulation of $\left[{ }^{3} \mathrm{H}\right]$ thymidine incorporation by fibroblasts. Partially purified growth factor (fraction 16 from Fig. 5A) was diluted 100 -fold with noncycling medium and placed on noncycling HFL-1 fibroblasts $\left(3.0 \pm 0.1 \times 10^{5} / 35-\mathrm{mm}\right.$ dish) in the presence of $\left[{ }^{3} \mathrm{H}\right]$ thymidine. Samples were harvested at the times indicated and processed as described in Methods. $\left[{ }^{3} \mathrm{H}\right]$ thymidine incorporation by fibroblasts in noncycling medium in the absence of growth factor was subtracted from each data point.

complementation test was performed to allow classification of the alveolar macrophage-derived growth factor as a competence or progression factor. This evaluation of the fibroblast growth response to partially purified macrophage derived growth factor required the use of a characterized progression factor (multiplication stimulating activity), as well as a characterized competence factor (platelet-derived growth factor or fibroblast growth factor).

In this complementation test, none of the growth factors individually caused any increase in fibroblast replication rate (Fig. 7). Moreover, when either platelet-derived growth factor or fibroblast growth factor was added to complementation medium containing multiplication-stimulating activity, at least a $40 \%$ in- 


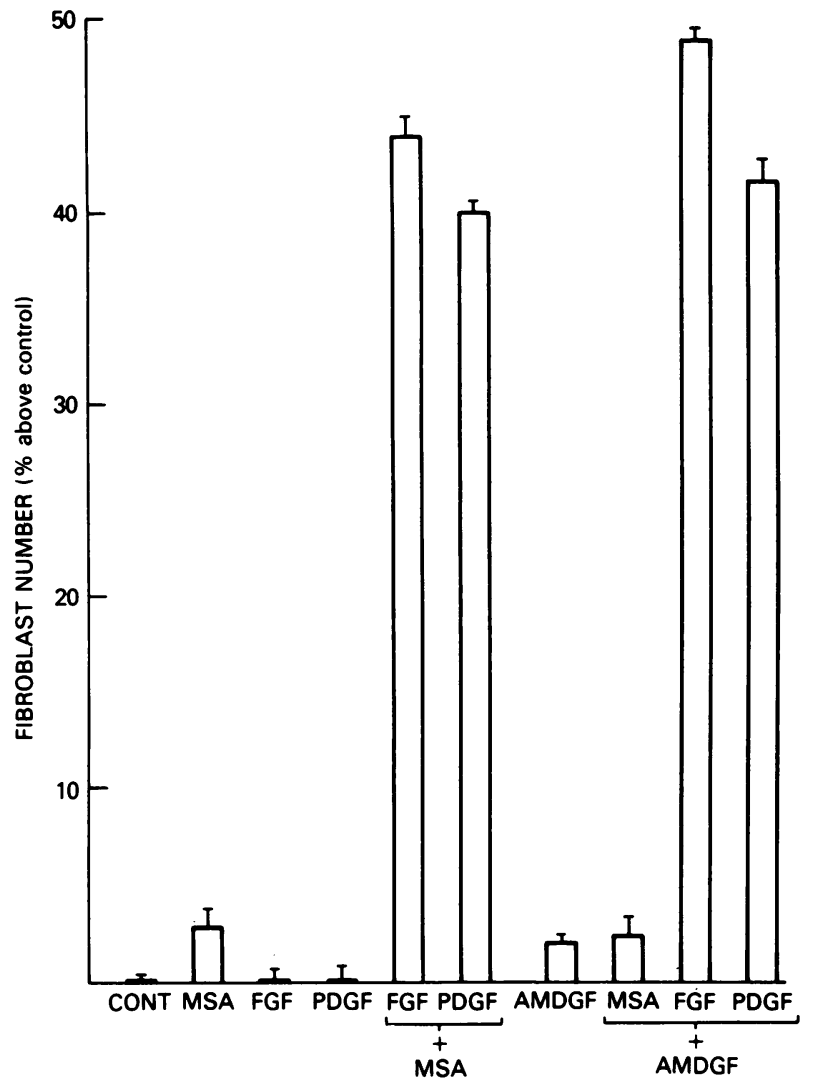

Figure 7 Evaluation of alveolar macrophage derived growth factor in a complementation test. Fibroblasts incubated in DMEM plus bovine serum albumin $(1 \mathrm{mg} / \mathrm{ml})$ for $3 \mathrm{~d}$ were cultured in the presence of the indicated growth factors for $72 \mathrm{~h}$. CONT, control; MSA, multiplication stimulating activity $(2 \mathrm{ng} / \mathrm{ml}) ; \mathrm{FGF}$, fibroblast growth factor $(2 \mathrm{ng} / \mathrm{ml})$; PDGF, platelet-derived growth factor $(0.1 \mathrm{U} / \mathrm{ml})$; and AMDGF, alveolar macrophage-derived growth factor (1:100 dilution of DEAE-cellulose partially purified growth factor). Fibroblast growth is expressed as the percentage increase in cell number above that observed in medium without any growth factors added. (FGF + MSA) and (PDGF + MSA) served as positive controls.

crease in fibroblast numbers above control resulted after $72 \mathrm{~h}$ of incubation. Culture of fibroblasts in complementation medium with macrophage-derived growth factor alone or together with multiplication stimulating activity caused no stimulation of fibroblast replication, i.e., the macrophage factor did not act as a competence factor. In marked contrast, macrophagederived growth factor cultured with either fibroblast growth factor or platelet-derived growth factor caused a significant increase in fibroblast replication after $\mathbf{7 2}$ $\mathrm{h}$ of incubation. Fibroblast number increased $49 \%$ above control with the macrophage factor plus fibroblast growth factor and $42 \%$ above control with the macrophage factor plus platelet derived growth factor $(P<0.001$, both comparisons compared with control).
Thus, in this complementation test, the macrophagederived growth factor acted as a progression factor. The necessity of having both a competence factor and a progression factor in the test system used was confirmed by our observing no increase in fibroblast replication with a 10-fold increase in the concentration of fibroblast growth factor alone or platelet-derived growth factor alone, or a 10 -fold increase in the concentration of multiplication stimulating activity together with several concentrations $\left(10^{-1}-10^{-6}\right)$ of macrophage-derived growth factor (data not shown).

Evaluation of DNA synthesis by fibroblasts in response to partially purified alveolar macrophage-derived growth factor provided further confirmation that the alveolar macrophage-derived growth factor was a progression factor. Different dilutions of partially purified macrophage-derived growth factor $\left(10^{-2}-\right.$ $10^{-7}$ ) were combined with platelet-derived growth factor $(0.1 \mathrm{U} / \mathrm{ml})$ in complementation test medium. Significant increases in $\left[{ }^{3} \mathrm{H}\right]$ thymidine incorporation were observed with the macrophage factor diluted up to $10^{-5}(24,000 \pm 1,100 \mathrm{dpm}$ above control), with peak incorporation observed at a dilution of $10^{-3}$ $(29,000 \pm 1,300 \mathrm{dpm}$ above control; $P<0.01$, all comparisons with controls; data not shown). Neither platelet-derived growth factor alone nor alveolar macrophage-derived growth factor alone caused any increase in $\left[{ }^{3} \mathrm{H}\right]$ thymidine incorporation above control $(1,350 \pm 250 \mathrm{dpm})$. Similar results were obtained when fibroblasts were cultured with alveolar macrophagederived growth factor and fibroblast growth factor $(2$ $\mathrm{ng} / \mathrm{ml}$ ).

Relationship of alveolar macrophage-derived growth factor to other characterized growth factors. Comparison of the macrophage-derived growth factor with other characterized growth factors suggested that it was unique. The apparent molecular weight of the alveolar macrophage-derived growth factor $(18,000)$ was clearly different from that of the insulin-somatomedin family of growth factors $(5,000-8,000)(7)$, epidermal growth factor $(5,000)(36)$, and the forms of human colony-stimulating factor purified to homogeneity $(40,000)$ (37) (Fig. 5B). Fibroblast growth factor $(15,000)(38)$ and platelet-derived growth factor $(30,000)(39)$ were distinguished from the macrophage factor by DEAE cellulose chromatography which demonstrated that the macrophage factor eluted at $0.27 \mathrm{M} \mathrm{NaCl}$, whereas fibroblast growth factor and platelet-derived growth factor eluted at the front $(0.02$ $\mathrm{M} \mathrm{NaCl}$ ) of the column (Fig. 5A). In addition, both platelet-derived growth factor and fibroblast growth factor bound to carboxymethyl-cellulose, whereas macrophage-derived growth factor did not (data not shown).

Although human growth hormone cochromatographed with macrophage-derived growth factor dur- 
ing both ion exchange and gel filtration, radioimmunoassay showed the partially purified macrophage factor to have no antigenic cross reactivity with human growth hormone. Radioimmunoassay also revealed the alveolar macrophage-derived growth factor to have no antigenic cross-reactivity to multiplication-stimulating activity or somatomedin C. Furthermore, radioreceptor assay demonstrated that the macrophage factor was not insulinlike growth factor $\mathrm{I} /$ somatomedin $\mathrm{C}$ or insulinlike growth factor II/somatomedin A/multiplication-stimulating activity.

Although the macrophage-derived growth factor for fibroblasts has a molecular weight similar to interleukin-1, and both bind to DEAE-cellulose, interleukin1 elutes before $0.10 \mathrm{M} \mathrm{NaCl}$, whereas the macrophagederived growth factor does not elute until $0.27 \mathrm{M} \mathrm{NaCl}$ (30). In addition, interleukin-1 was inactive in the fibroblast growth assay used (Fig. 8A) and the macrophage-derived growth factor was inactive in the standard interleukin-1 mouse thymocyte proliferation assay used (Fig. 8B).

Comparison of alveolar macrophage-derived growth factor with the other previously described macrophage-derived growth factors for fibroblasts (from hu- man blood monocytes as well as from guinea pig and mouse peritoneal macrophages) revealed some biochemical similarities. In common with the alveolar macrophage factor all were nondialyzable (14-18), and where examined their biological activity was destroyed by boiling $(15,17)$ (data not shown). The guinea pig peritoneal macrophage factor elutes with two peaks of activity using gel filtration, one similar to the human alveolar factor at $\sim 10,000-15,000$ daltons and a second at $\sim 40,000-60,000$ daltons (18). However, the elution pattern of the 15,000-dalton guinea pig factor using ion exchange chromatography has not been characterized. The murine peritoneal macrophage factor, like the alveolar factor, did not bind to carboxymethyl-cellulose, but it chromatographed in the void volume of a Sephadex G-100 column, which suggests a higher molecular weight (17). Thus, the alveolar macrophage-derived growth factor shared some biochemical features in common with other macrophage derived-growth factors for fibroblasts, although it appeared to be distinct.

Growth of different alveolar fibroblast strains in response to partially purified macrophage-derived growth factor. Several strains of normal alveolar fi-

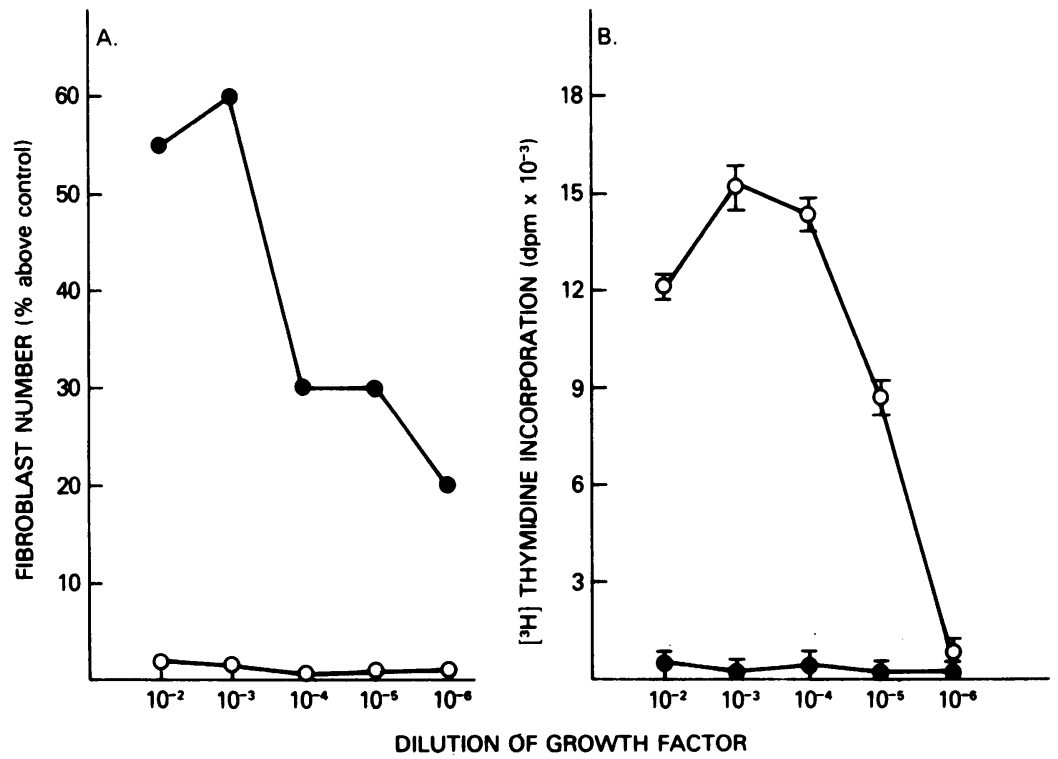

Figure 8 Comparison of alveolar macrophage-derived growth factor with interleukin-1 for their effect on fibroblast growth and thymocyte DNA synthesis. (A) Comparison of alveolar macrophage-derived growth factor with interleukin-l for their effect on fibroblast growth. Fibroblasts in complementation test medium were cultured with platelet-derived growth factor $(0.1 \mathrm{U} / \mathrm{ml})$ at the indicated dilution of DEAE-cellulose partially purified alveolar macrophagederived growth factor $(\bullet)$ or partially purified interleukin-1 (O). Media without any growth factors served as a control. (B) Comparison of alveolar macrophage-derived growth factor with interleukin-1 for their effect on thymocyte DNA synthesis. Thymocytes were cultured in the presence of either DEAE-cellulose partially purified alveolar macrophage-derived growth factor $(\bullet)$; or partially purified interleukin-1 $(O)$. Media alone served as a control. Shown is thymocyte $\left[{ }^{3} \mathrm{H}\right]$ thymidine incorporation in response to each factor; $\left[{ }^{3} \mathrm{H}\right]$ thymidine incorporation in the absence of any growth factor was subtracted from each point. 
broblasts in addition to HFL-1 were found to be responsive to the macrophage-derived growth factor. Evaluation of five strains in a complementation test with platelet-derived growth factor $(0.1 \mathrm{U} / \mathrm{ml}) \mathrm{de}$ monstrated that each alveolar fibroblast had its own characteristic dose-response curve to the macrophagederived growth factor (Fig. 9). HFL-1 and P-7 are human fetal alveolar fibroblast strains; strains 86,47 , and 22 are normal human adult alveolar fibroblasts. The two fetal strains and adult strain 47 were significantly more sensitive to alveolar macrophage-derived growth factor than were strains 86 and $22(P<0.01$, all comparisons). Each strain had a characteristic max-

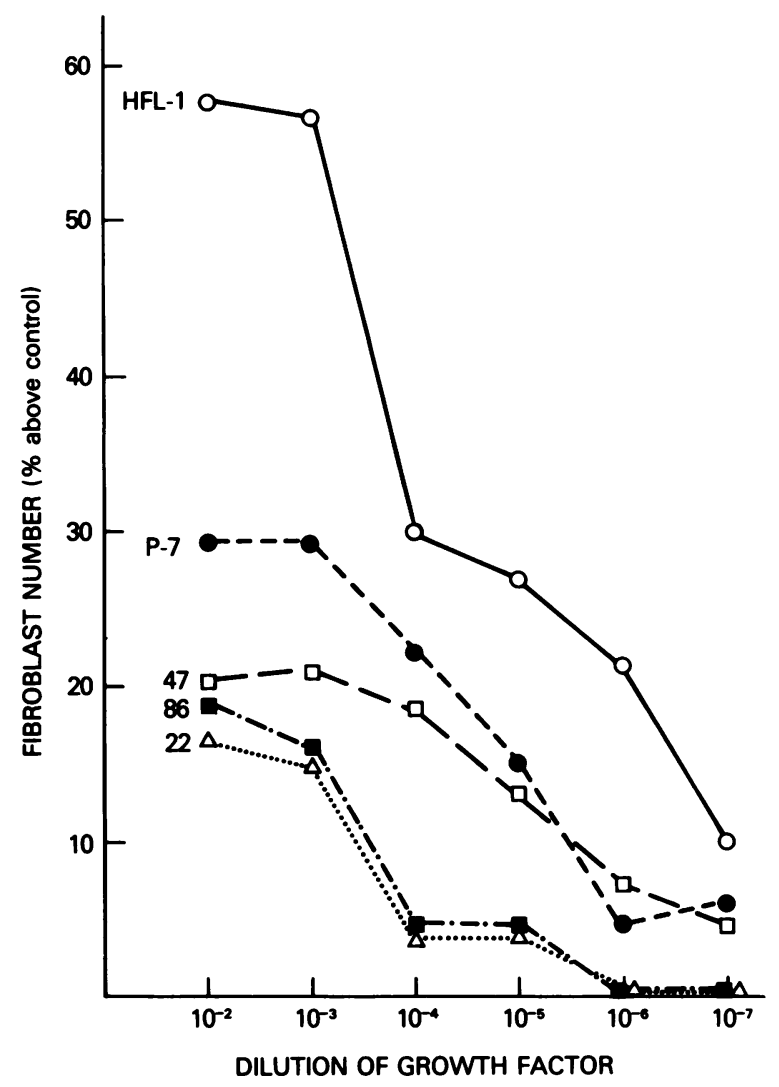

Figure 9 Response of five normal human lung fibroblast strains to various dilutions of partially purified alveolar macrophage-derived growth factor. Each of the five strains of fibroblasts were cultured at $5 \times 10^{4}$ cells $/ 35-\mathrm{mm}$ dish in complementation test medium as described in Methods. Plateletderived growth factor $(0.1 \mathrm{U} / \mathrm{ml})$ was added with varying dilutions of the macrophage-derived growth factor to the fibroblast cultures. The fibroblasts were incubated for $72 \mathrm{~h}$ and then counted. For each strain, complementation test medium alone served as a control. Shown is the percentage increase in cell number above control for lung fibroblast strains HFL-1 (O), P-7 (๑), $47(\square), 86(\square)$, and $22(\Delta)$ in response to decreasing amounts of alveolar macrophage-derived growth factor. imum response to alveolar macrophage-derived growth factor, with the two fetal strains showing significantly larger increases in fibroblast number than did the three adult strains $(P<0.01$, all comparisons). Similar results were obtained when these strains were evaluated in noncycling media in the standard growth factor assay rather than in a complementation test (data not shown).

\section{DISCUSSION}

Maintenance of the normal fibroblast population size within the alveolar structures is thought to result from a balance of stimulatory and inhibitory signals within the local milieu. In this context, the present study suggests that alveolar macrophages, members of the mononuclear phagocyte family of cells, may control, in part, the population size of fibroblasts in the alveolar structures by releasing a growth factor that increases the rate of relication of lung fibroblasts.

Stimulated human alveolar macrophages are capable of releasing a growth factor causing noncycling human lung fibroblasts to replicate. This alveolar macrophage-derived growth factor induces fibroblast DNA synthesis within $12 \mathrm{~h}$, with cell division detectable by $48 \mathrm{~h}$. The growth factor is released by alveolar macrophages rapidly following stimulation by particulates, immune complexes, or surface attachment. Partial purification reveals the factor to be a macromolecule of $\sim 18,000$ daltons that stimulates fibroblast replication in the nanomolar to picomolar range, and that appears to be distinct from other characterized growth factors. Though unable to stimulate fibroblast replication by itself in serum-free conditions, the alveolar macrophage-derived growth factor can be classified as a progression factor, providing a growth-promoting signal to noncycling fibroblasts that is complementary to that provided by competence factors such as fibroblast growth factor and platelet-derived growth factor.

Mononuclear phagocyte control of cellular replication. Alveolar macrophage release of the growth factor for lung fibroblasts is one of several examples of the ability of mononuclear phagocytes to modulate cell replication by secreting growth promoting mediators. In this context, colony-stimulating factor(s) that cause granulocyte-monocyte precursors in the bone marrow to replicate are released by human blood monocytes (40) and alveolar macrophages (12), as well as by murine peritoneal macrophages (41). In addition, interleukin-1, a growth factor augmenting the replication rate of certain lymphocytes subpopulations, is released by human blood monocytes and alveolar macrophages from a variety of animal sources (42-47). Furthermore, like human alveolar macrophages, human blood monocytes, guinea pig peritoneal macro- 
phages, and murine peritoneal macrophages release a growth factor that signals fibroblasts to replicate (14-18). Moreover, rabbit wound macrophages and guinea pig peritoneal macrophages release an activity promoting the replication of both vascular smooth muscle cells and vascular endothelial cells $(17,48)$. Thus, mononuclear phagocytes appear to serve an important role in controlling the replication of a variety of cells throughout the body.

Alveolar macrophages do not produce the growth factor for fibroblasts unless stimulated by an appropriate agent. This pattern is similar to release of nearly all mononuclear phagocyte-derived growth factors studied. In this regard, mononuclear phagocytes are able to recognize diverse inflammatory and immune signals such as the $\mathrm{Fc}$ portion of IgG, $\mathrm{C} 3 \mathrm{~b}$, and particulates $(49,50)$. Such signals not only result in mononuclear phagocyte release of growth factors for fibroblasts (14-18), but also in release of interleukin-1 (44) and colony-stimulating factor(s) (40). In this context, the concept of mononuclear phagocyte activation by inflammatory and immune signals should include the release of growth factors in addition to mediators such as lysosomal hydrolases, prostaglandins, proteases, plasminogen activator, reactive oxidant species, and neutrophil chemotactic factor $(22,51-56)$.

Although many agents that activate mononuclear phagocytes cause alveolar macrophages to release the growth factor for fibroblasts, there is clearly a hierarchy among the effective agents with regard to the amount of growth factor released. This observation is consistent with studies demonstrating that mononuclear phagocyte activation is not a single state characterized by maximal release of all mediators, but a set of states with the response of the mononuclear phagocyte dependent on the activating agent. For example, Unanue et al. (44) have shown that although both microorganisms and immune complexes stimulate elicited mouse peritoneal macrophages to release interleukin-1, microorganisms are a more effective stimulus than are immune complexes. With regard to metabolic concomitants of macrophage activation, Karnovsky et al. (57) have demonstrated that although both microorganisms and nonspecific inflammatory agents such as caseinate are able to activate mouse peritoneal macrophages to release both hydrolases and plasminogen activator, metabolic activation is induced only by microorganisms and not by nonspecific inflammatory agents. In addition, Cohn (58) has shown that although lymphokines and nonspecific inflammatory agents cause the characteristic spreading, metabolic, and secretory changes associated with activation, only lymphokines confer microbicidal properties to the macrophage. Moreover, Glenn and Ross (15) have shown that although endotoxin, concanavalin $\mathrm{A}$, zymosan, and surface adherence all result in mononuclear phagocyte release of a growth factor for fibroblasts, endotoxin and conconavalin $A$ are far more effective than zymosan or adherence. Thus, the finding that various agents are differentially effective in promoting release of the alveolar macrophage-derived growth factor is consistent with substantial precedent concerning a hierarchy of macrophage mediator release in response to a variety of activating agents.

Kinetics of release of the alveolar macrophage-derived growth factor. After appropriate stimulation, alveolar macrophages rapidly release the growth factor for fibroblasts, with maximal levels seen within 3-4 h. This rapid release of the growth factor by human alveolar macrophages after stimulation is similar to that observed by de Lustro et al. (16) using human blood monocytes and by Leibovich and Ross (14) using guinea pig peritoneal macrophages. The absence of preformed active growth factor in alveolar macrophages coupled with rapid release of this mediator after appropriate macrophage stimulation suggests that it is stored as an inactive precursor that can be rapidly converted to an active form. Preliminary experiments using cycloheximide and actinomycin D suggest that the amount of growth factor released during the first 1-2 $\mathrm{h}$ after stimulation is not dependent on de novo RNA or protein synthesis. However, release of growth factor after this time appears to be dependent on both RNA and protein synthesis. In addition, it is known that many macrophage mediators other than growth factors for fibroblasts are also released in this time period after stimulation. For example, the growth factors, colony-stimulating factor (41), and interleukin-1 (59), as well as the inflammatory mediators neutrophil chemotactic factor (22), reactive oxidant species (56), lysosomal hydrolases (60), and prostaglandin $E_{2}(61)$ are all detected in macrophage supernates within a few hours after stimulation of macrophages. In this context, considered as a group, mononuclear phagocyte-derived growth factors can be categorized with those macrophage mediators released relatively soon after activation.

The relatively rapid release of growth factors by mononuclear phagocytes in response to appropriate signals supports the concept that the target cells for mononuclear-derived growth factors can be regarded as a population of relatively slowly replicating cells that can be rapidly signaled to divide by activated mononuclear phagocytes. As an example, Leibovich and Ross $(14,62)$ established a model for wound healing in which macrophages, recruited to the site of wounding, were activated by elements of the inflammatory milieu to release a growth factor that rapidly signalled slowly replicating skin fibroblasts to increase their rate of replication, leading to normal scar for- 
mation. In this context it is noteworthy that the immune and inflammatory signals that stimulate alveolar macrophages to release the growth factor for fibroblasts are those that in vivo are likely associated with damage to the alveolar structures and the need for rapid tissue repair.

Biological properties of the alveolar macrophagederived growth factor. Although the mechanism of action of growth factors is not known, one useful system for classifying growth factors is based on the dualcontrol model of the cell cycle proposed by Stiles et al. (33). Many growth factors can be conveniently divided into two categories, competence factors and progression factors. Competence factors act early in the $G_{1}$ phase of the cell cycle, rendering a cell competent for a variable number of hours to respond to progression factors, which act sometime later in $\mathrm{G}_{1}$ to promote cell replication (63). In common with the insulinlike growth factor/somatomedin family of growth factors, the alveolar macrophage-derived growth factor for fibroblasts is a progression factor (33).

As a general principle, fibroblast replication in tissue culture requires both a competence factor and a progression factor. In the context of the alveolar structures, a corollary of this principle is that initiation of lung fibroblast replication probably involves a competence factorlike signal in addition to the progression activity supplied by the macrophage-derived growth factor. The source of such a competence factor in the alveolar structures is unknown. One source may be another soluble mediator released by macrophages or other effector cells. Alternatively, competence may be conferred upon lung fibroblasts continuously by their interaction with the interstitial matrix in a manner similar to that suggested by Gospodarowicz and Ill (64) in relation to endothelial cell replication. If the interstitial matrix does play this role in providing competence, macrophage-derived growth factor release could be sufficient to initiate lung fibroblast replication within the alveolar structures.

For the alveolar macrophage-derived growth factor to act as progression factor it must interact with the fibroblast surface in some manner. In this context, most characterized progression factors recognize a single class (or two closely related classes) of surface receptors that appear to mediate their growth-promoting effect (65). The ability of a growth factor to bind this receptor can be assessed by using a chick embryo fibroblast radioreceptor assay that uses a common receptor to recognize most characterized progression factors, which are in the insulinlike growth factor/somatomedin family of growth factors (66). Surprisingly, although the alveolar macrophage-derived growth factor for fibroblasts acts as a progression factor, it has no affinity for this surface receptor. One possible ex- planation for this observation derives from the work of Clemmons et al. (67), who demonstrated that human growth hormone can stimulate human lung fibroblasts to produce their own somatomedin $\mathrm{C}$, which in turn stimulates fibroblast replication. In this context, the alveolar macrophage-derived growth factor may act as a progression factor by inducing fibroblasts to produce and release an endogenous progression factor.

Possible role of alveolar macrophage-derived growth factor in controlling the population size of fibroblasts within the alveolar structures. Available information suggests that under normal circumstances the rate of fibroblast replication within the alveolar structures is very low, implying that the net balance of growth regulatory signals present is not sufficient to promote fibroblast replication (68). In this context, alveolar macrophages from normal individuals do not release detectable amounts of the growth factor for fibroblasts unless activated. However, in several interstitial lung disorders associated with inflammation of the alveolar structures and activated macrophages, there are marked local accumulations of fibroblasts, which suggests that fibroblast replication is occurring. For example, in oxygen toxicity both morphometric and autoradiographic studies have demonstrated large increases in fibroblast replication rate $(69,70)$.

Current concepts of the pathogenesis of interstitial lung disorders suggest that the process begins with stimuli that lead to alveolar inflammation characterized by increased numbers of activated immune and inflammatory cells. Heppleston and Styles (71) first focused attention on macrophages activated by silica as an important constituent of the inflammatory milieu within the alveolar structures in silicosis. In this context, in idiopathic pulmonary fibrosis, a chronic, progressive form of interstitial fibrosis, there are large numbers of macrophages within the alveolar structures that have been activated by immune complexes (72). Significantly, immune complexes cause alveolar macrophages to release the growth factor for fibroblasts, and preliminary studies of patients with idiopathic pulmonary fibrosis suggest that in most cases, alveolar macrophages from these individuals are spontaneously producing the growth factor for fibroblasts (73). Thus, it is possible that in fibrotic lung disease associated with alveolar macrophage activation, release of the growth factor for fibroblasts may play a role in the expansion of the numbers of fibroblasts within the alveolar structures that characterizes these disorders.

\section{ACKNOWLEDGMENTS}

The authors wish to thank S. P. Nissley, National Cancer Institute, for performing the radioreceptor assay for somatomedin A, somatomedin C, multiplication-stimulating activity, and insulinlike growth factors I and II, as well as the 
radioimmunoassay for multiplication stimulating activity; N. Beaudry, Department of Radiochemistry, Hazleton Laboratories America, Vienna, VA, for performing the radioimmunoassay for human growth hormone; and Nichols Institute, Los Angeles, CA, for performing the radioimmunoassay for somatomedin C. We would also like to thank J. Davidson for his useful suggestions, $S$. Adelberg for excellent technical assistance, and E. Duncan for editorial assistance.

\section{REFERENCES}

1. Weibel, E. R, P. Gehr, D. Haies, and M. Bachofen. 1976. The cell population of the normal lungs. In Lung cells in disease. A. Bouhuys, editor. Amsterdam, North-Holland Biomedical Press. 3-16.

2. Ueki, A., Y. Fukushima, and T. Kimoto. 1976. C3b and C3d receptor sites on human diploid fibroblasts. Virchows Arch. B. Cell. Path. 21: 13-15.

3. Papmichril, M., P. W. Faulk, C. Gutierrez, A. Temple, and P. M. Johnson. 1979. Binding of native and aggregated human gamma-globulin by mouse lymphoid cells and fibroblasts. Clin. Immunol. Immunopath. 12: 426442.

4. Kapanci, Y., A. Assimacopoulos, C. Irle, A. Zwahlen, and G. Gabbiani. 1974. "Contractile interstitial cells" in pulmonary alveolar septa: a possible regulator of ventilation/perfusion ratio. J. Cell Biol. 60: 375-392.

5. Van Leuven, F., J. J. Cassiman, and H. Van Den Berghe. 1978. Uptake and degradation of $\alpha 2$ macroglobulin-protease complexes in human cells in culture. Exp. Cell. Res. 177: 273-282.

6. Yamanaka, N., and D. Deamer. 1974. Superoxide dismutase activity in WI-38 cell cultures: effects of age, trypsinization and SV-40 transformation. Physiol. Chem. Phys. 6: 95-106.

7. VanWyk, J. J., and R. L. Hintz. Peptide growth factors. 1979. Endocrinology. 3: 1767-1775.

8. Ross, R., and G. H. Sato. Cell culture and endocrinology: an overview. 1979. In Hormones and Cell Culture, Book B. G. H. Sato and R. Ross, editors. Cold Spring Harbor Laboratory. 965-971.

9. Todaro, G., Y. Matsuya, S. Bloom, A. Robbins, and H Green. 1967. Stimulation of RNA synthesis and cell division in resting cells by a factor present in serum. In Growth Regulatory Substances for Animal Cells in Culture. V. Detendi and M. Stoker, editors. Philadelphia, Wistar Institute Press. 87-101.

10. Temin, H. M. 1967. Control by factors in serum of multiplication of uninfected cells and cells infected and converted by avian Sarcoma virus. In Growth Regulatory Substances for Animal Cells in CUlture. V. Detendi and M. Stoker, editors. Philadelphia, Wistar Institute Press. 103-116.

11. Barry, D. E., J. D. Crapo, P. Gehr, M. Bachofen, and E. R. Weibel. 1979. Population characteristics of the cells in normal lung. Am. Rev. Respir. Dis. 119(Pt. 2): 287.

12. Golde, D. W., T. N. Finley, and M. J. Cline. 1972. Production of colony stimulating factor by human macrophages. Lancet. II: 1397-1399.

13. Gery, I., and B. H. Waksman. 1972. Potentiation of the T-lymphocyte response to mitogens. II. The cellular source of potentiating mediator(s). J. Exp. Med. 136: 143-155.

14. Leibovich, S. J., and R. Ross. 1976. A macrophage-dependent factor that stimulates the proliferation of fibroblasts in vitro. Am. J. Pathol. 84: 501-513.
15. Glenn, K. C., and R. Ross. 1981. Human monocyte-derived growth factor(s) for mesenchymal cells: activation of secretion by endotoxin and concanavalin A. Cell. 25: 603-615.

16. DeLustro, F., G. K. Sherer, and E. C. LeRoy. 1980. Human monocyte stimulation of fibroblast growth by a soluble mediator(s). J. Reticuloendothel. Soc. 28: 519532 .

17. Martin, B. M., M. A. Gimbrone, Jr., E. R. Unanue, and R. S. Cotran. 1981. Stimulation of nonlymphoid mesenchmal cell proliferation by a macrophage derived growth factor. J. Immunol. 126: 1510-1515.

18. Wahl, S. M., L. M. Wahl, J. B. McCarthy, L. Chedid, and S. E. Mergenhagen. 1979. Macrophage activation by mycobacterial water soluble compounds and synthetic muramyl dipeptide. J. Immunol. 122: 2226-2231.

19. Baserga, R. and D. Malamud. 1969. Autoradiography: Techniques and Applications. New York, Evanston, and London, Harper and Row.

20. Hunninghake, G. W., J. E. Gadek, O. Kawanami, V. J. Ferrans, and R. G. Crystal. 1979. Inflammatory and immune processes in the human lung in health and disease: evaluation by bronchoalveolar lavage. Am. J. Pathol. 97: 149-206.

21. Mosier, D. E. 1967. A requirement for 2 cell types for antibody formation in vitro. Science (Wash. DC). 158: 1573-1575.

22. Hunninghake, G. W., J. E. Gadek, H. M. Fales, and R. G. Crystal. 1980. Human alveolar macrophage-derived chemotactic factor for neutrophils: Stimuli and partial characterization. J. Clin. Invest. 66: 473-483.

23. Vogel, A., E. Raines, B. Kariya, M. J., Rivest, and R Ross. 1978. Coordinate control of 3T3 cell proliferation by platelet derived growth factor and plasma components. Proc. Natl. Acad. Sci. U. S. A. 75: 2810-2814.

24. Odell, W. D., P. L. Rayford, and G. T. Ross. 1967. Simplified, partially automated method for radioimmunoassay of human thyroid-stimulating, growth, luteinizing, and follicle stimulating hormones. J. Lab. Clin. Med. 70: 973-979.

25. Moses, A. C., S. P. Nissley, J. Passamani, R. M. White, and M. M. Rechler. 1979. Further characterization of growth hormone dependent somatomedin-binding proteins in rat serum and demonstration of somatomedin binding proteins produced by rat liver cells in culture. Endocrinology. 104: 536-546.

26. Rechler, M. M., J. M. Podskalny, and S. P. Nissley. 1977. Characterization of the binding of multiplication stimulating activity to a receptor for growth polypeptides in chick embryo fibroblasts. J. Biol. Chem. 252: 38983910.

27. Moses, A. C., S. P. Nissley, P. A. Short, and M. M. Rechler. 1980. Immunological crossreactivity of multiplication stimulating activity polypeptides. Eur. J. Biochem. 103: 401-408.

28. Furlanetto, R. W., L. E. Underwood, J. J. VanWyk, and A. J. D'Ercole. 1977. Estimation of somatomedin C levels in normals and patients with pituitary disease by radioimmunoassay. J. Clin. Invest. 60: 648-657.

29. Mizel, S. B., J. J. Oppenheim, and D. L. Rosenstreich. 1978. Characterization of lymphocyte-activating factor (LAF) produced by the macrophage cell line, P388D I. Enhancement of LAF production by activated T-lymphocytes. J. Immunol. 120: 1497-1503.

30. Mizel, S. B., J. J. Oppenheim, and D. L. Rosenstreich. 1978. Characterization of lymphocyte-activating factor (LAF) produced by a macrophage cell line, $\mathrm{P}_{338 \mathrm{D}_{1}}$, II. 
Biochemical characterization of LAF induced by activated T-cells and LPS. J. Immunol. 120: 1504-1508.

31. Gillis, S., M. M. Ferm, W. Ou, and K. A. Smith. 1978. T-cell growth factor: parameters of production and a quantitative microassay for activity. J. Immunol. 120: 2027-2032.

32. Schrier, B. K., and S. H. Wilson. 1976. On the measurement of tritium in DNA and its application to the assay of DNA polymerase activity. Methods Cell Biol. 13: 105-120.

33. Stiles, C. D., G. T. Capone, C. D. Scher, H. N. Antoniades, J. J. VanWyk, and W. J. Pledger. 1979. Dual control of cell growth by somatomedins and platelet derived growth factor. Proc. Natl. Acad. Sci. U. S. A. 76: 12791283.

34. Bradley, K. H., O. Kawanami, V. J. Ferrans, and R. G. Crystal. 1980. The fibroblast of human lung alveolar structures: a differentiated cell with a major role in lung structure and function. Methods Cell Biol. 21A: 37-64.

35. Burn, J. H., D. J. Finney, and L. G. Goodwin. 1950. Biological Standardization. London, New York, Ontario, Oxford University Press.

36. Savage, C. R., and S. Cohen. 1972. Epidermal growth factor and a new derivative. Rapid isolation procedures and biological and chemical characterization. J. Biol. Chem. 247: 7609-7611

37. Wu, M-C., and A. Fischer. 1980. Granulocyte and macrophage colony-stimulating factor from human placenta conditioned medium. Biochemistry. 19: 3846-3850.

38. Gospodarowicz, D. 1975. Purification of a fibroblast growth factor from bovine pituitary. J. Biol. Chem. 250: 2515-2520.

39. Heldin, C. H., B. Westermark, and A. Wasterson. 1979 Platelet derived growth factor: purification and partial characterization. Proc. Natl. Acad. Sci. U. S. A. 76: 3722-3726.

40. Burgess, A. W., and D. Metcalf. 1980. The nature and action of granulocyte-macrophage colony stimulating factors. Blood. 56: 947-958.

41. Eaves, A. C., and W. R. Bruce. 1974. In vitro production of colony stimulating activity I. Exposure of mouse peritoneal cells to endotoxin. Cell Tissue Kinet. 7: 19-30.

42. Gery, I., and R. E. Handschumacher. 1974. Potentiation of the T-lymphocyte response to mitogens. III. Properties of the mediator(s) from adherent cells. Cell. Immunol. 11: 162-169.

43. Hunninghake, G. W., P. Broska, R. Haber, B. A. Keogh, B. R. Line, and R. G. Crystal. 1981. Correlation of lung $\mathrm{T}$-cell and macrophage function with disease activity in pulmonary sarcoid. Clin. Res. 49: 550A.

44. Unanue, E. R., J. M. Kiely, and J. Calderdon. 1976. The modulation of lymphocyte functions by molecules secreted by macrophages. II. Conditions leading to increased secretion. J. Exp. Med. 144: 155-166.

45. Katz, S. P., T. Shimamura, J. P. Dessaint, D. Braverman, and B. H. Waksman. 1980. Mechanisms of action of "lymphocyte-activating factor" (LAF). IV. Differential stimulation of T-lymphocytes by induced macrophage enzymes (catheptic carboxypeptidase $B$ and serine proteases). Cell. Immunol. 56: 68-79.

46. Ulrich, F. 1977. Studies of lymphocyte activating factor from alveolar macrophages. J. Reticuloendothel. Soc. 21: $33-51$.

47. Murphy, P. A., P. L. Simon, and W. F. Wiloughby. 1980. Endogenous pyrogens made by rabbit peritoneal exudate cells are identical with lymphocyte activating factors made by rabbit alveolar macrophages. J. Immunol. 124: 2498-2501.

48. Greenburg, G., and T. Hunt. 1978. The proliferative response in vitro of vascular endothelial and smooth muscle cells exposed to wound fluids and macrophages. J. Cell. Physiol. 97: 353-360.

49. Reynolds, H., J. Atkinson, H. Newball, and M. Frank. 1975. Receptors for immunoglobulin and complement on human alveolar macrophages. J. Immunol. 114: 1813-1819.

50. Green, G. M., and E. H. Kass. 1964. The role of the alveolar macrophage in the clearance of bacteria from the lung. J. Exp. Med. 119: 167-176.

51. Axline, S. G., and Z. A. Cohn. 1979. In vitro induction of lysosomal enzymes by phagocytosis. J. Exp. Med. 131: 1239-1260.

52. Morley, J., M. A. Bray, R. W. Jones, D. H. Nugtason, and P. A. VanDorp. 1979. Prostaglandin and thromboxane production by human and guinea pig macrophages and leukocytes. Prostaglandins. 17: 729-746.

53. Werb, Z., and S. Gordon. 1975. Secretion of a specific collagenase by stimulated macrophages. J. Exp. Med. 142: $346-360$.

54. Werb, Z., and S. Gordon. 1975. Elastase secretion by stimulated macrophages. J. Exp. Med. 142: 361-377.

55. Gordon, S., J. C. Unkeless, and Z. A. Cohn. 1974. Induction of macrophage plasminogen activator by endotoxin stimulation and phagocytosis. Evidence for a two-stage process. J. Exp. Med. 140: 995-1010.

56. Johnston, R. B., Jr., C. A. Godzik, and Z. A. Cohn. 1978. Increased superoxide anion production by immunologically activated and chemically elicited macrophages. J. Exp. Med. 148: 115-127.

57. Karnovsky, M. L., J. Lazdins, and S. R. Simmons. 1975. Metabolism of activated mononuclear phagocytes at rest and during phagocytosis. In Mononuclear Phagocytes. R. VanFurth, editor. Oxford, London, Edinburgh Melbourne, Blackwell Scientific Publications. 423-438.

58. Cohn, Z. A. 1978. The activation of mononuclear phagocytes: fact, fancy, and future. J. Immunol. 121: 814816.

59. Blyden, G., and R. E. Handschumacher. 1977. Purification and properties of human lymphocyte activating factor. J. Immunol. 118: 1631-1638.

60. Davies, P., R. C. Page, and A. C. Allison. 1974. Changes in cellular enzyme levels and extracellular release of lysosomal acid hydrolases in macrophages exposed to group A streptococcal cell wall substance. J. Exp. Med. 139: $1262-1282$

61. Bonney, R. J., P. D. Wightman, P. Davies, S. J. Sadowski, F. A. Kuehl, Jr., and J. Humes. 1978. Regulation of prostaglandin synthesis and of the selective release of lysosomal hydrolases by mouse peritoneal macrophages. Biochem. J. 176: 433-442.

62. Leibovich, S. J., and R. Ross. 1975. The role of the macrophage in wound repair. A study with hydrocortisone and antimacrophage serum. Am. J. Pathol. 78: 71-91.

63. VanWyk, J. J., L. E. Underwood, A. J. D'Ercole, D. R Clemmons, W. J. Pledger, W. R. Wharton, and E. B. Leof. 1981. Role of somatomedin in cellular proliferation. In The Biology of Normal Human Growth. M. Ritzen, A. Aperia, K. Atall, A. Larsson, and A. Zetterberg, editors. New York, Raven Press. 223-239.

64. Gospodarowicz, D., and C. Ill. 1980. Extracellular matrix and control of proliferation of vascular endothelial cells. J. Clin. Invest. 65: 1351-1364. 
65. Kasuga, M., E. VanOberghen, S. P. Nissley, and M. M. Rechler. 1981. Demonstration of two subtypes of insulinlike growth factor receptors by affinity crosslinking. $J$. Biol. Chem. 256: 5305-5308.

66. Moses, A. C., S. P. Nissley, M. M. Rechler, P. A. Short, and J. M. Podskalny. 1979. The purification and characterization of multiplication stimulating activity (MSA) from media conditioned by a rat liver cell line. In Somatomedins and Growth. G. Geordano, J. J. VanWyk, and F. Minuto, editors. London, New York, San Francisco, Academic Press. 45-59.

67. Clemmons, D. R., L. E. Underwood, and J. J. VanWyk. 1981. Hormonal control of immunoreactive somatomedin production by cultured human fibroblasts. J. Clin. Invest. 67: 10-19.

68. Evans, M. J., and R. F. Bils, 1969. Identification of cells labelled with activated thymidine in the pulmonary alveolar walls of the mouse. Am. Rev. Respir. Dis. 100: 372-378.
69. Crapo, J. D., M. Peters-Golden, J. Marsh-Salin, and J. S. Shelburne. 1978. Pathologic changes in the lungs of oxygen-adapted rats: a morphometric analysis. $L a b$. Invest. 39: 640-653.

70. Adamson, I. Y. R., and D. H. Bowden, 1976. Pulmonary injury and repair. Organ culture studies of murine lung after oxygen. Arch. Pathol. Lab. Med. 110; 640-643.

71. Heppleston, A. G., and J. A. Styles. 1967. Activity of a macrophage factor in collagen formation by silica. $\mathrm{Na}$ ture (Lond.). 214: 521-522.

72. Hunninghake, G. W., J. E. Gadek, T. J. Lawley, and R. G. Crystal. 1981. Mechanisms of neutrophil accumulation in the lungs of patients with idiopathic pulmonary fibrosis. J. Clin. Invest. 68: 259-269.

73. Bitterman, P. B., and R. G. Crystal. 1981. Alveolar macrophages (AM) in idiopathic pulmonary fibrosis (IPF) and sarcoidosis are spontaneously secreting a growth factor causing human lung fibroblasts to replicate. Clin. Res. 49: 443A. 